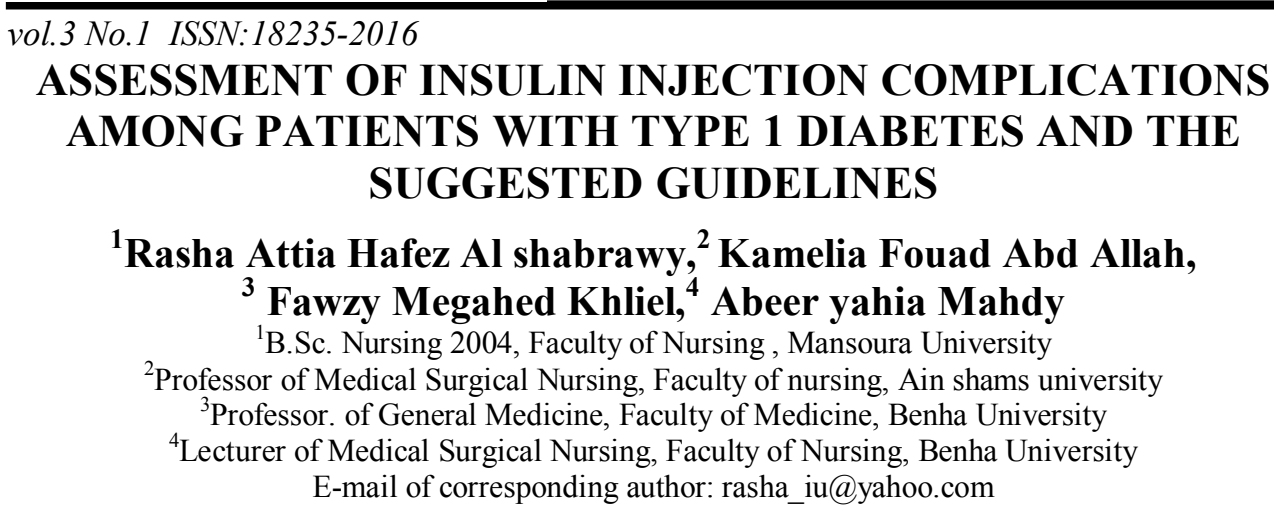

${ }^{1}$ Rasha Attia Hafez Al shabrawy, ${ }^{2}$ Kamelia Fouad Abd Allah,

${ }^{3}$ Fawzy Megahed Khliel, ${ }^{4}$ Abeer yahia Mahdy

${ }^{1}$ B.Sc. Nursing 2004, Faculty of Nursing, Mansoura University

${ }^{2}$ Professor of Medical Surgical Nursing, Faculty of nursing, Ain shams university

${ }^{3}$ Professor. of General Medicine, Faculty of Medicine, Benha University

${ }^{4}$ Lecturer of Medical Surgical Nursing, Faculty of Nursing, Benha University

E-mail of corresponding author: rasha_iu@yahoo.com

\begin{abstract}
:
Increasing the prevalence of DM has emergence of diabetes complications as a cause of early morbidity and mortality. The aim of present study was to assess the insulin injection complications among patients with $\mathrm{T}_{1} \mathrm{DM}$, and suggest the nursing intervention guidelines for patients with $\mathrm{T}_{1} \mathrm{DM}$. Research design used was descriptive exploratory study. A purposive sample included 100 patients diagnosed with $\mathrm{T}_{1} \mathrm{DM}$ from both genders. The study was carried out in outpatient clinics at Benha university hospital. Two tools were used to collect data;1) Interview questionnaire sheet; it consisted of three parts A)Patients' demographic data , B)Patients' medical history, C) Patients' lifestyle assessment sheet, 2) Patients' assessment sheet; it consisted of two parts A) Assessment of patients' level of knowledge, B) Assessment of insulin injection complications. The study results revealed that more than two third of the studied patients $(68 \%)$ had mild insulin injection complications and nearly one third $(32 \%)$ had moderate insulin injection complications, most of patients $(75 \%)$ had unsatisfied level of knowledge about the disease, complications, and management, and more than half of patients $(59 \%)$ had unhealthy lifestyle pattern. It can be concluded that there was a statistical significant difference between patients' total systematic insulin injection complications in relation to their personal data including age, residency, and level of educations, also there was a statistical significant difference between patients' total systematic insulin injection complications in relation to onset of insulin injection treatment $(\mathrm{p}<0.05)$. The studied patients' total local and systematic insulin injection complications correlated negatively with their total lifestyle pattern and total level of knowledge with statistical insignificant differences $(\mathrm{P}>0.05)$. The study recommended application of guiding educational and cultural programs for patients with DM to improve their knowledge about treatment regimen, correct insulin injection technique, complications, and it preventive and curative management.
\end{abstract}

Key words: Benha, nursing, diabetes mellitus, insulin injection complications, lifestyle.

\title{
Introduction:
}

Diabetes mellitus (DM) is a complex, chronic illness requiring continuous medical care with multifactorial risk reduction strategies beyond glycemic control. Ongoing patient self-management education and support are critical to preventing acute complications and reducing the risk of long-term complications (American Diabetes Association (ADA), 2014).

The estimated worldwide prevalence of diabetes of all types was 285 million adults in the year 2010, and is projected to rise to 439 million 
Rasha Attia Hafez Al shabrawy et. al.

in 2030. Specifically, in the United States, the American Diabetes Association estimated the prevalence of diabetes to be 25.8 million ( $8.3 \%$ of the country's population) during 2007(Shaw, Sicree, and Zimmet, 2010).

According to David, (2011)DM is classified into four broad categories: $T_{1} D M, \quad T_{2} D M$, gestational diabetes, and other specific types. The $\mathrm{T}_{1} \mathrm{DM} \quad$ (Immune-mediated diabetes); this form of diabetes, previously encompassed by the terms insulin-dependent diabetes, or juvenile-onset diabetes, results from a cellular-mediated autoimmune destruction of the $\beta$-cells of the pancreas, age of onset usually younger than 30 years and can occur at any age, , and onest is usually abrupt with rapid onest of hyperglycemia, patients often present with acute symptoms of diabetes and markedly elevated blood glucose levels, and some cases are diagnosed with life-threatening ketoacidosis (Redondo, Jeffrey, Fain, Eisenbarth, and Orban,2008).

The $\mathrm{T}_{1} \mathrm{DM}$ is caused by destruction of the insulin-producing pancreatic islet cells, over time, as more and more pancreatic islet cells become damaged, the body's insulin levels begin to drop. Eventually, the body no longer is capable of producing enough insulin to properly manage blood glucose regulation, resulting in hyperglycemia, or elevated levels of glucose in the blood. In some cases, however, patients' experience what is referred to as a "honeymoon period" shortly after $\mathrm{T}_{1} \mathrm{DM}$ is diagnosed, during which the patient's diabetic symptoms seem to go away for a period of a few months to a year, insulin needs can become minimal during this time, and some patients may indeed find they can maintain normal or near-normal blood glucose levels with little or no insulin administration (Donna\&Linda, 2013).

The hallmark symptom of $\mathrm{T}_{1} \mathrm{DM}$ is hyperglycemia, which is defined as blood glucose levels $>130 \mathrm{mg} / \mathrm{dL}$ in the fasting state or $>180 \mathrm{mg} / \mathrm{dL}$ after meals. However, hyperglycemia is a symptom of both $\mathrm{T}_{1} \mathrm{DM}$ and $\mathrm{T}_{2} \mathrm{DMand}$ therefore cannot be used to aid in the differentiation of these conditions. In addition to hyperglycemia, the most common symptoms of $\mathrm{T}_{1} \mathrm{DM}$ are Polyuria (increased urination), polydipsia (increased thirst) and polyphagia (increased appetite)(Smith\&Cockrell, 2013).

There is presently no cure for $\mathrm{T}_{1} \mathrm{DM}$; instead, it is a chronic and lifelong condition that requires patients to adhere to a prescribed diet and therapeutic regimen. With faithful adherence, patients with $\mathrm{T}_{1} \mathrm{DM}$ may live a long life and experience less frequent and less severe diabetesrelated complications. This adherence include lifelong commitment of patients to frequent monitoring of blood glucose levels, taking regular doses of insulin, following a diet designed to manage blood sugar levels and participating in an active exercise routine and maintaining hygienic care (Donna\& Linda, 2013).

According to current ADA recommendations, most people with 
$\mathrm{T}_{1} \mathrm{DM}$ should be treated with multidose insulin injections (3 to 4 injections per day of basal and preprandial insulin) or continuous subcutaneous insulin infusions (via insulin pump) to manage blood glucose levels. In addition, people with $\mathrm{T}_{1} \mathrm{DM}$ should be taught how to match preprandial insulin doses to planned carbohydrate intake, premeal blood glucose, and anticipated activity levels to help maintain target blood glucose levels (Khardori\& Griffing, 2013and $A D A, 2013)$.

Despite the benefits of insulin therapy, many people with diabetes don't adhere to treatment. Some avoid insulin therapy or refuse to start it. A recent study found more than a third of the roughly 25 million Americans with diabetes don't take insulin as prescribed and $20 \%$ intentionally skip some doses, which can lead to serious health risks. Incorrect injection technique can lead to unpredictable absorption, causing hypoglycemia or hyperglycemia. Other potential problems include lipohypertrophy or lipoatrophy. It is recommended that as much attention is given to injection technique as to the agent being injected (Pledger,Hicks, Kirkland, and Down, 2012).

\section{Significance of the study:}

The DM has long been considered a disease of minor significance to world health, but is now developing into one of the main public health challenges for the $21 \mathrm{st}$ century (Masur, Thévenod, and Znker, 2008). The DM remains an incurable disorder which is associated with poor quality of life, cardiovascular complications, increased mortality and morbidity. The recent statistics shows that the global prevalence of this disorder continues to rise unabated and thus becoming an epidemic (Diabetes Control and Complications Trial, 2009)

patients present with uncontrolled hyperglycemia which can be managed only with insulin therapy, besides the existing challenges in the management of uncontrolled diabetes and its related complications, another difficulty which is commonly faced by the nursing staff and the physicians, is the lack of awareness regarding insulin injection techniques; in appropriate insulin injection practices can lead to various clinical complications such as poor glycemic control, pain, bleeding and bruising, breaking and lodging of needle tip beneath the skin, contamination leading to infection, and in accurate dose administration(Bajwa,Kalra, Baruah, and Bajwa, 2013).

Aim of the study:

The present study was conducted to fulfill the following aim:

$>$ Assess the insulin injection complications among patients with type 1diabetes.

- Suggest the nursing intervention guidelines for patients with type 1 diabetes.

\section{Research Question:}

- Is there insulin injection complications among patients with type 1 diabetes? 
- Is there a relation between insulin injection complications and patients' demographic data?

- Is there a relation between insulin injection complications and patients' lifestyle?

- Is there a relation between insulin injection complications and patients' knowledge?

- Is there a relation between insulin injection complications and period \& doses of insulin injection?

Subjects and methods:

\section{Research design:}

A descriptive exploratory design was utilized in this study.

\section{Research Setting:}

The study was conducted in outpatient clinics at Benha University Hospital in medical clinic which concerned with caring of medical and diabetic patients.

\section{Subjects:}

A purposive sample of 100 patients diagnosed with $\mathrm{T}_{1} \mathrm{DM}$. Subjects were recruited for the study with the following inclusion criteria, adult patients $\left(\mathrm{T}_{1} \mathrm{DM}\right)$ treated with insulin therapy (subcutaneous insulin injection) for more than one year, both gender, able to communicate and agree to participate in the study. The exclusion criteria were Patients with diabetes under 18 years old, patients with any skin problem, mentally retarded patients and obese patients.

Tools for Data Collection:
Three tools were piloted and used by the researcher to collect data including:

\section{Tools for data collection:}

Two tools were piloted and used by the researcher to collect data including:

Tool I: Interview Questionnaire sheet; which consisted of 3 parts:

Part 1: Personal Data:

It was composed of (8) closed ended questions including (age, sex, marital status, residence, level of education, occupation, income, received training programs).

Part 2: Patients' Medical History: it consisted of three parts:

(A)Past Medical History:

it was composed of (2) questions including (duration of the disease, onset of insulin injection treatment).

\section{(B)Family history:}

it was composed of (2) questions including (family history of diabetes, degree of relatively).

\section{(C)Present history:}

it was composed of (10) questions including (complications of diabetes, type of complications, other medication taken with insulin injection, allergy to any drug, number of follow up in outpatient clinic, rate of testing blood glucose level, way to test blood glucose level, insulin self injection, who teach correct technique, who inject insulin if not self injection).

\section{Part 3: Patients' lifestyle assessment} sheet:

it was composed of six domains including (27) questions about patients' lifestyle pattern including; diet (4questions), exercise (5 questions), medication (6 questions), 
smoking (3 questions), stress (4 questions), and hygiene (5 questions).

Tool II: Patients' assessment sheet; it consisted of two parts:

\section{Part 1: Patients' knowledge} questionnaire sheet:

It consisted of (32) questions about patients' knowledge about insulin injection complications, and the nursing intervention assessment. It was formed of multiple choice questions.

Part 2: Assessment the insulin injection complications:

It developed by the researcher, constructed and reviewed utilizing the most recent and relevant literature Which includes complications of insulin injection that the patients suffering from. It includes two main domains; local complications (10 items) and systematic complications (8 items).

\section{Pilot study:}

A pilot study was conducted on group 10 patients with DM in order to test the clarity and applicability of the study tools. Required modifications were done in the form of adding or omission of some questions.

\section{Administrative design:}

An official permission to carry out the study was obtained by submission of official letters from the dean of faculty of nursing Benha University to the director of Benha University Hospital, head of nursing, and head nurse of outpatient clinics.

\section{Ethical consideration:}

Ethical approval was obtained from the Scientific Ethical Committee of Benha University. The purpose of the study was explained to the patients and oral consent was obtained from them to participate in this study. They were given an opportunity to withdraw from the study without given a reason and they were assured that anonymity and confidentiality of information was protected. Ethics, values, culture, and beliefs were respected.

\section{Statistical analysis:}

The obtained data were organized, categorized, analyzed through a personal computer using the statistics package for social sciences(SPSS).Data were presented using descriptive statistics in the form of frequencies and percentages. Statistical significance was considered at $\mathrm{P} \leq 0.05$, highly significance $\mathrm{P}<$ 0.001 and insignificant was considered at $\mathrm{P}>0.05$. Also cronbach's alpha test was used to test the reliability of the tool. 
Rasha Attia Hafez Al shabrawy et. al.

\section{Result:}

Table (1): Frequency and percentage distribution of personal characteristics of the studied patients $(n=100)$.

\begin{tabular}{|c|c|c|}
\hline Sociodemographic Characteristics & Frequency & $\%$ \\
\hline \multicolumn{3}{|l|}{ Age groups (in years) } \\
\hline $18-<30$ & 11 & 11.0 \\
\hline $30-<40$ & 11 & 11.0 \\
\hline $40-<50$ & 16 & 16.0 \\
\hline$\geq 50$ & 62 & 62.0 \\
\hline $11.69 \pm S D$ & \multicolumn{2}{|l|}{$49.75 \pm$ Mean } \\
\hline \multicolumn{3}{|l|}{ Gender } \\
\hline Male & 41 & 41.0 \\
\hline Female & 59 & 59.0 \\
\hline \multicolumn{3}{|l|}{ Residence } \\
\hline Urban & 14 & 14.0 \\
\hline Rural & 86 & 86.0 \\
\hline \multicolumn{3}{|l|}{ Marital status } \\
\hline Single & 5 & 5.0 \\
\hline Married & 82 & 82.0 \\
\hline Divorced & 3 & 3.0 \\
\hline Widowed & 10 & 10.0 \\
\hline \multicolumn{3}{|l|}{ Level of education } \\
\hline Illiterate & 42 & 42.0 \\
\hline Read \& write & 14 & 14.0 \\
\hline Secondary education & 35 & 35.0 \\
\hline University education & 9 & 9.0 \\
\hline \multicolumn{3}{|l|}{ Occupation } \\
\hline Not working & 17 & 17.0 \\
\hline Retired & 9 & 9.0 \\
\hline Housewife & 40 & 40.0 \\
\hline Written work & 18 & 18.0 \\
\hline Professional work & 16 & 16.0 \\
\hline \multicolumn{3}{|l|}{ Monthly Income } \\
\hline Enough & 45 & 45.0 \\
\hline Not enough & 55 & 55.0 \\
\hline \multicolumn{3}{|c|}{ Received training programs of insulin injection } \\
\hline Yes & 4 & 4.0 \\
\hline No & 96 & 96.0 \\
\hline Type of received training programs & \multicolumn{2}{|c|}{$\mathrm{n}=4$} \\
\hline Lecture of protection from diabetes complications & 2 & 50.0 \\
\hline Lecture on diabetes & 2 & 50.0 \\
\hline
\end{tabular}


The characteristics of the study sample are described in table (1): illustrates that more than two third $(47 \%)$ of studied subjects were in age group from 55 years to 65 years, with mean $56.6 \pm 10.5$, and $(41.0 \%)$ of them were illiterate, respectively.

Table (2): Frequency and percentage distribution of studied patients in relation to their past and family history $(\mathrm{n}=100)$.

\begin{tabular}{|l|c|c|}
\hline \multicolumn{1}{|c|}{ Past and family history } & Frequency & $\%$ \\
\hline Duration of diabetes mellitus & 6 & 6.0 \\
\hline $1<3 \mathrm{Y}$ & 7 & 7.0 \\
\hline $3<5 \mathrm{Y}$ & 87 & 87.0 \\
\hline$>5 \mathrm{Y}$ & \multicolumn{2}{|l|}{} \\
\hline Onset of insulin injection treatment & 6 & 6.0 \\
\hline $1<3 \mathrm{y}$ & 7 & 7.0 \\
\hline $3<5 \mathrm{y}$ & 87 & 87.0 \\
\hline$\geq 5 \mathrm{y}$ & 76 & 76.0 \\
\hline Family history of diabetes & 24 & 24.0 \\
\hline Yes & \multicolumn{2}{|c|}{$\mathrm{n}=76$} \\
\hline No & 42 & 55.3 \\
\hline Degree of relatively & 34 & 44.7 \\
\hline First degree & \multicolumn{2}{|l}{} \\
\hline Second degree & \multicolumn{3}{|l|}{} \\
\hline
\end{tabular}

This table showed that, most of diabetic patients $(87 \%)$ had diabetes and treated with insulin injection for more than five years, and also( $76 \%)$ of them had family history of diabetes with more than one third of them $(55.3 \%)$ had first degree of relatively.

Table (3): Frequency and percentage distribution of studied patients according to their level of knowledge $(n=100)$.

\begin{tabular}{|c|c|c|c|c|}
\hline \multirow{2}{*}{ Total knowledge Score } & \multicolumn{2}{|c|}{ Unsatisfactory } & \multicolumn{2}{c|}{ Satisfactory } \\
\cline { 2 - 5 } & No & $\mathbf{\%}$ & No & $\mathbf{\%}$ \\
\hline Total level of knowledge of the studied patients & 75 & 75.0 & 25 & 25.0 \\
\hline
\end{tabular}

Table (3): shows the levels of knowledge of the studied subjects. This table showed that three quarters of the studied patients $(75 \%)$ had unsatisfactory level of knowledge, and only one quarter of them $(25 \%)$ had satisfactory level of knowledge. 
Rasha Attia Hafez Al shabrawy et. al.

Table (4): Frequency and percentage distribution of diabetic patients according to their total lifestyle items $(n=100)$.

\begin{tabular}{|l|c|c|c|c|}
\hline \multirow{2}{*}{ Total lifestyle } & \multicolumn{2}{|c|}{ Healthy lifestyle } & \multicolumn{2}{c|}{ Unhealthy lifestyle } \\
\cline { 2 - 5 } & $\mathbf{N}$ & $\mathbf{\%}$ & $\mathbf{N}$ & $\%$ \\
\hline Diet & 84 & 84.0 & 16 & 16.0 \\
\hline Exercise & 9 & 9.0 & 91 & 91.0 \\
\hline Medication & 51 & 51.0 & 49 & 49.0 \\
\hline Smoking & 97 & 97.0 & 3 & 3.0 \\
\hline Stress & 46 & 46.0 & 54 & 54.0 \\
\hline Hygiene & 81 & 81.0 & 19 & 19.0 \\
\hline Total lifestyle & 41 & 41.0 & 59 & 59.0 \\
\hline
\end{tabular}

This table showed that more than one third of the studied patients $(41 \%)$ had healthy lifestyle pattern.

Table (5): Frequency and percentage distribution of the studied patients according to their insulin injection complications $(\mathrm{n}=100)$.

\begin{tabular}{|l|c|c|c|c|}
\hline \multirow{2}{*}{ Items } & \multicolumn{2}{|c|}{ Occurred } & \multicolumn{2}{c|}{ Not occurred } \\
\cline { 2 - 5 } & $\mathbf{N}$ & $\mathbf{\%}$ & $\mathbf{N}$ & $\mathbf{\%}$ \\
\hline Local insulin injections complications & & & & \\
\hline Lipoatrophy & 45 & 45.0 & 55 & 55.0 \\
\hline Lipohypertrophy & 92 & 92.0 & 8 & 8.0 \\
\hline Bleeding and bruising & 15 & 15.0 & 85 & 85.0 \\
\hline Leakage of insulin & 19 & 19.0 & 81 & 81.0 \\
\hline Inflammation of injection site & 32 & 32.0 & 68 & 68.0 \\
\hline Infection of injection site & 4 & 4.0 & 96 & 96.0 \\
\hline Low sensitivity to injection pain & 35 & 35.0 & 65 & 65.0 \\
\hline Pain of injection rotated site & 77 & 77.0 & 23 & 23.0 \\
\hline Peripheral edema & 31 & 31.0 & 69 & 69.0 \\
\hline Local allergic reaction & 28 & 28.0 & 72 & 72.0 \\
\hline Systematic insulin injections complications & \multicolumn{5}{|c|}{} \\
\hline Hypoglycemia & 63 & 63.0 & 37 & 37.0 \\
\hline Somogyi effect & 36 & 36.0 & 64 & 64.0 \\
\hline Dawen phenomenon & 22 & 22.0 & 78 & 78.0 \\
\hline Hyperglycemia & 94 & 94.0 & 6 & 6.0 \\
\hline DKA & 45 & 45.0 & 55 & 55.0 \\
\hline HHNK syndrome & 0 & 0 & 100 & 100.0 \\
\hline Drug interaction & 2 & 2.0 & 98 & 98.0 \\
\hline Insulin resistant & 17 & 17.0 & 83 & 83.0 \\
\hline Total insulin injection complications & Total insulin injection complications \\
\cline { 2 - 5 } & $\mathbf{N}$ & $\mathbf{\%}$ & \multicolumn{2}{|c|}{ Mean \pm SD } \\
\hline No insulin injection complications & 0 & 0.0 & & \\
\hline Mild insulin injection complications & 68 & 68.0 & $30.6 \pm 1.3$ \\
\hline Moderate insulin injection complications & 32 & 32.0 & $26.9 \pm 1.5$ \\
\hline Sever insulin injection complications & 0 & 0.0 & & \\
\hline
\end{tabular}


This table showed that more than two third of the studied patients $(68 \%)$ had mild insulin injection complications and nearly one third $(32 \%)$ had moderate insulin injection complications.

Table (6) : Association between the studied patients' total local and systematic insulin injection complications and their personal characteristics $(n=100)$.

\begin{tabular}{|c|c|c|c|c|}
\hline \multirow{2}{*}{$\begin{array}{l}\text { Total insulin injection } \\
\text { complications } \\
\text { Sociodemographic } \\
\text { Characteristics }\end{array}$} & $\begin{array}{c}\text { Total local insulin } \\
\text { injection } \\
\text { complications }\end{array}$ & \multirow[t]{2}{*}{$\begin{array}{c}\text { Test of } \\
\text { significance }\end{array}$} & $\begin{array}{c}\text { Total systematic } \\
\text { insulin injection } \\
\text { complications }\end{array}$ & \multirow[t]{2}{*}{$\begin{array}{c}\text { Test of } \\
\text { significance }\end{array}$} \\
\hline & Mean \pm SD & & Mean \pm SD & \\
\hline \multicolumn{5}{|l|}{ Age groups (in years) } \\
\hline $18-<30$ & $16.4 \pm 0.9$ & \multirow{4}{*}{$\begin{array}{c}\text { One Way Anova } \\
\mathrm{F}=0.50 \\
\mathrm{P}=0.68\end{array}$} & $12.8 \pm 1.5$ & \multirow{4}{*}{$\begin{array}{c}\text { One Way Anova } \\
\begin{array}{c}\mathrm{F}=3 \\
\mathbf{P}=\mathbf{0 . 0 3 3}\end{array}\end{array}$} \\
\hline $30-<40$ & $16.4 \pm 1.2$ & & $14 \pm 1.3$ & \\
\hline $40-<50$ & $16.3 \pm 1.2$ & & $13.5 \pm 1.1$ & \\
\hline$\geq 50$ & $16 \pm 1.3$ & & $13 \pm 1.2$ & \\
\hline \multicolumn{5}{|l|}{ Gender } \\
\hline Male & $16.1 \pm 1.2$ & \multirow{2}{*}{$\begin{array}{l}\mathrm{t}=-0.03 \\
\mathrm{P}=0.97\end{array}$} & $13.1 \pm 1.3$ & \multirow{2}{*}{$\begin{array}{c}\mathrm{t}=-0.49 \\
\mathrm{P}=0.620\end{array}$} \\
\hline Female & $16.2 \pm 1.2$ & & $13.3 \pm 1.4$ & \\
\hline \multicolumn{5}{|l|}{ Residence } \\
\hline Urban & $16.1 \pm 1.1$ & \multirow{2}{*}{$\begin{array}{l}\mathrm{t}=-0.17 \\
\mathrm{P}=0.85\end{array}$} & $12.6 \pm 1.6$ & \multirow{2}{*}{$\begin{array}{c}\mathrm{t}=1.74 \\
\mathbf{P}=\mathbf{0 . 0 5 4}\end{array}$} \\
\hline Rural & $16.2 \pm 1.3$ & & $13.2 \pm 1.2$ & \\
\hline \multicolumn{5}{|l|}{ Marital status } \\
\hline Single & $16.8 \pm 1.09$ & \multirow{4}{*}{$\begin{array}{c}\text { One Way Anova } \\
\begin{array}{c}\mathrm{F}=0.87 \\
\mathrm{P}=0.45\end{array} \\
\end{array}$} & $13.6 \pm 2$ & \multirow{4}{*}{$\begin{array}{c}\text { One Way Anova } \\
\begin{array}{c}\mathrm{F}=0.77 \\
\mathrm{P}=0.50\end{array}\end{array}$} \\
\hline Married & $16.1 \pm 1.2$ & & $13.2 \pm 1.2$ & \\
\hline Divorced & $17 \pm 1$ & & $13.6 \pm 0.5$ & \\
\hline Widowed & $16.3 \pm 1.8$ & & $12.7 \pm 1.7$ & \\
\hline \multicolumn{5}{|l|}{ Level of education } \\
\hline Illiterate & $16.1 \pm 1.3$ & \multirow{4}{*}{$\begin{array}{c}\text { One Way } \\
\text { Anova } \\
\mathrm{F}=0.97 \\
\mathrm{P}=0.406\end{array}$} & $12.9 \pm 1.1$ & \multirow{4}{*}{$\begin{array}{c}\text { One Way } \\
\text { Anova } \\
\mathrm{F}=2.6 \\
\mathbf{P}=\mathbf{0 . 0 5 4} \text { * }\end{array}$} \\
\hline Read \& write & $16 \pm 1.5$ & & $13.4 \pm 1.3$ & \\
\hline Secondary education & $16.1 \pm 1$ & & $13.1 \pm 1.2$ & \\
\hline University education & $16.8 \pm 1.1$ & & $14.2 \pm 1.4$ & \\
\hline \multicolumn{5}{|l|}{ Occupation } \\
\hline Not working & $16.2 \pm 1.2$ & \multirow{5}{*}{$\begin{array}{c}\text { One Way } \\
\text { Anova } \\
\mathrm{F}=0.16 \\
\mathrm{P}=0.95\end{array}$} & $13.1 \pm 1.1$ & \multirow{5}{*}{$\begin{array}{c}\text { One Way } \\
\text { Anova } \\
\mathrm{F}=1.9 \\
\mathrm{P}=0.10\end{array}$} \\
\hline Retired & $16 \pm 1.4$ & & $12.4 \pm 1.2$ & \\
\hline Housewife & $16.2 \pm 1.3$ & & $13.1 \pm 1.2$ & \\
\hline Written work & $16 \pm 1.2$ & & $13.8 \pm 1.2$ & \\
\hline Professional work & $16.3 \pm 1.1$ & & $13 \pm 1.4$ & \\
\hline \multicolumn{5}{|l|}{ Monthly Income } \\
\hline Enough & $16 \pm 1.4$ & \multirow{2}{*}{$\begin{array}{l}\mathrm{t}=-0.78 \\
\mathrm{P}=0.43\end{array}$} & $13 \pm 1.5$ & \multirow{2}{*}{$\begin{array}{l}\mathrm{t}=-1.2 \\
\mathrm{P}=0.21\end{array}$} \\
\hline Not enough & $16.2 \pm 1.1$ & & $13.3 \pm 1.1$ & \\
\hline \multicolumn{5}{|c|}{ Received training programs } \\
\hline Yes & $16 \pm 0.81$ & \multirow{2}{*}{$\begin{array}{l}\mathrm{P}=0.75 \\
\mathrm{t}=-0.31\end{array}$} & $12.2 \pm 1.5$ & \multirow{2}{*}{$\begin{array}{l}\mathrm{t}=-1.4 \\
\mathrm{P}=0.13\end{array}$} \\
\hline No & $16.2 \pm 1.2$ & & $13.2 \pm 1.2$ & \\
\hline
\end{tabular}

* Significant (S) p $\leq \mathbf{0 . 0 5}$

Insignificant (S) $\mathrm{p}>\mathbf{0 . 0 5}$

This table showed that there was statistical significant difference between the studied patients' total systematic insulin injection complications in relation to their age, residency, and level of education $(\mathrm{p} \leq 0.05)$. 
Table (7) Association between the studied patients' total local and systematic insulin injection complications and onset of insulin injection treatment, and number of insulin injections per day $(\mathrm{n}=100)$.

\begin{tabular}{|c|c|c|c|c|}
\hline \multirow{2}{*}{ Items } & $\begin{array}{c}\text { Total local insulin } \\
\text { injection complications }\end{array}$ & \multirow[t]{2}{*}{ Test of significance } & $\begin{array}{l}\text { Total systematic insulin } \\
\text { injection complications }\end{array}$ & \multirow[t]{2}{*}{$\begin{array}{c}\text { Test of } \\
\text { significance }\end{array}$} \\
\hline & Mean \pm SD & & Mean \pm SD & \\
\hline \multicolumn{5}{|c|}{ Onset of insulin injection treatment } \\
\hline $1<3 y$ & $16.3 \pm 1.5$ & \multirow{3}{*}{$\begin{array}{c}\text { One Way Anova } \\
\mathrm{F}=1.3 \\
\mathrm{P}=0.27\end{array}$} & $13.7 \pm 1.4$ & \multirow{3}{*}{$\begin{array}{c}\text { One Way } \\
\text { Anova } \\
\mathrm{F}=3.4 \\
\mathbf{P}=\mathbf{0 . 0 3 7}\end{array}$} \\
\hline $3<5 y$ & $16.6 \pm 1.1$ & & $13.8 \pm 1$ & \\
\hline$\geq 5 \mathrm{y}$ & $16.1 \pm 1.2$ & & $13 \pm 1.2$ & \\
\hline \multicolumn{5}{|c|}{ Number of insulin injections per day } \\
\hline One dose & $16.5 \pm 1.4$ & \multirow{3}{*}{$\begin{array}{c}\text { One Way Anova } \\
\mathrm{F}=1.1 \\
\mathrm{P}=0.33\end{array}$} & $13.2 \pm 1.4$ & \multirow{3}{*}{$\begin{array}{c}\text { One Way } \\
\text { Anova } \\
\mathrm{F}=0.55 \\
\mathrm{P}=0.57\end{array}$} \\
\hline Two doses & $16.1 \pm 1.2$ & & $13.2 \pm 1.2$ & \\
\hline Three doses & $15.8 \pm 1.1$ & & $12.6 \pm 1.8$ & \\
\hline
\end{tabular}

This table showed that there was statistical significant difference between the patients' total systematic insulin injection complications in relation to onset of insulin injection treatment $(\mathrm{p}<0.05)$.

\section{Disscussion:-}

The findings of the present study revealed that, more than half of the studied patient ages were more than 50 years old with mean (standard deviation) was 49.75 (11.69) this is in accordance with Clark et al (2011) who reported that mean age of his studied subjects was 39 years (range 20-55 years), also Hirsch(2012)who reported that age of his studied subjects ranged from 19 to 74 years (mean 55.6 years), also this is in accordance with(Butalia, et al,2013) who reported that mean (standard deviation) age in his studies was 40.0 (15.8) years,

As regard to gender, the results of the present study showed that, female patients represent more than half of the study sample; this finding was in agreement with many studies in which the higher incidence of $\mathrm{T}_{1} \mathrm{DM}$ was among females Selim (2000), AbuSamara (2005), Abd El-Aziz (2007), Hassan (2007), and Nafee and Awad (2008). Also Munib,(2009),Moustafa, (2011), Abd El-monem, (2012) and Hirsch (2012) all reported that more than half of their studies patients were female, also Riaz, (2014)reported that the majority of his studied patients were female.

Regarding residence, the results of this study revealed that more than three quarters of the study sample were from rural area, this finding in agreement with findings of Abdel Hamid, (2005), Abu-Samara, (2005), Abd El-Aziz, (2007), and Galal, (2012)who reported that, more than half of their subjects were from rural areas.

In relation to marital status, the study findings showed that, more than 
three quarters of patients were married, this finding is agreement with Hassan (2007) and Galal (2012) who mentioned that the majority of their studied patients were married, and this finding might be due to same age groups of the studied sample.

Concerning educational level of the studied sample, the result of current study showed that the minority of patients had completed university degree and more than one third of them were illiterate. This in accordance with Abdel Hamid (2005) who reported that most of his studied sample were illiterate, and Galal (2012) who reported that one half of his studied sample could just read and write while the minority of them had completed university degree. Also this finding in accordance with Riaz, (2014) who reported that about half of his studied subjects had primary education as the highest level of education attained.

In relation to patients ' occupation, the study finding showed that nearly two third of the studied patient were not working (not work\& retired\& housewife) this finding in accordance with Galal (2012) who reported that more than one half of his studied patients were not working .These may be related to gender or complications occurred.

Regarding income, the study finding showed that more than half of study sample had not enough monthly income. This finding is in agreement with Wong et al (2003) who found adolescents who lived in shared home more exposed to disease because they have not enough money for treatment and care and Galal (2009) who reported that more than half of his patients had not enough monthly income.

Regarding receiving training programs, the study finding showed that the majority of the studied patient hadn't receiving any training programs, this finding in agreement with Attia, (2012) who reported that more than half of caregivers of school children with $\mathrm{T}_{1} \mathrm{DM}$ haven't receiving any training programs.

As regard to duration of diabetes, the present study revealed that most of studied patients had diabetes and treated with insulin injection for more than five years, this finding in agreement with Munib(2009), Moustafa (2011), Attia (2012)and Galal (2012)who reported that their studied subjects had disease for duration ranged from one up to ten years, this finding supported by Abd El-Ghaffar(2003) and Abd El-Aziz (2007)who reported that duration of diabetes among diabetic adolescents ranged from 1 to 12 years.

As regard to family history of diabetes, the present study revealed that three quarters of studied patients were having positive family history of diabetes, and more than half of them having first degree relativity, this finding is in agreement with Ratzan (2000), Cho (2003), and Abdel Hamid (2005) who reported that diabetes should be suspected with a strong family history of diabetes. Also this finding is in agreement with Abd El-Aziz (2007) who reported that 
diabetic adolescents had a positive family history of the disease, and Rewers et al(2010) who reported that, diabetes mellitus should be suspected in children with a strong family history of diabetes.

The current study revealed that more than one third of the studied patients had followed healthy lifestyle pattern, this finding in accordance with Shobana, (1999) who reported that only one third of his study respondents were following dietary prescriptions regularly. Additionally this finding in agreement with several studied done by Hammed (2001), Moustafa (2011), Attia (2012), and Galal (2012) all reported that there was significantly improvement in the reported dietary management among the studied subjects after implementing the self care programs.

Regarding the studied patients level of knowledge the current study revealed that three quarters of studied patients had unsatisfactory level of knowledge, and only one quarters had satisfactory level of knowledge, this finding in agreement with Attia (2012)who reported that more than half of his studied subjects had average knowledge, and minority revealed good knowledge this finding in agreement with Galal (2012)who reported that there was a highly statistically significant difference in total knowledge scores of diabetic patients with an extremely significant difference in mean knowledge scores after applying the education program.

Concerning insulin injection complications; more than two third of the studied patients had mild insulin injection complications and nearly one third had moderate insulin injection complications; this finding is in accordance with several studies reported that hypertrophy was the most common cutaneous complications of insulin therapy; Chowdhury and Escudier( 2003), Richardson and Kerr (2003), Villiers(2006), Vardar and Kizilci (2007), Munib(2009), and Cunningham (2013). who reported that over time, areas of lipohypertrophy and lipoatrophy, bruising, bleeding can develop as complications for insulin injection.

Concerning relation between patients' total local and systematic insulin injection complications in relation to their personal characteristics the present study revealed that there was a statistical significant difference between patients' total systematic insulin injection complications in relation to their age, residency, and level of education this finding was supported by Torrance, (2008) who reported that international guidelines identified the following points as important factors when considering insulin injection technique: injection sites, needle length, age of patient, gender of patient, BMI and pinch up, Dunning, (1998) who reported that number of factors complicated the diagnosis and management of possible insulin allergy: were patient's psychological history, and the long duration of insulin treatment before any localized reaction was reported. Also Riaz, (2014)who reported that some of the sociodemographic and service related 
factors are influencing the patient compliance, factors found to be significantly associated with non adherence of diabetic patients were cost of insulin, occupation of respondent's mother, family history of diabetes, poor understanding of prescription, irregularity of follow up, and fear of insulin.

A statistical significant difference was observed between patients' total systematic insulin injection complications in relation to onset of insulin injection treatment, this finding was supported by Conrad and Ferry (2014)who reported that short term overdosing of insulin causes short term insulin resistance, it has been hypothesized that chronic high dosing contributes to more permanent insulin resistance, if insulin resistance exists, more insulin are needs. If this compensatory increase does not occur, blood glucose concentrations increase. Also (AACE)2013 reported that the $\mathrm{A}_{1} \mathrm{c}$ target must be individualized based on numerous factors such as duration of diabetes,

\section{Conclusion}

The current study concluded that, more than two third of the studied patients had mild insulin injection complications and nearly one third had moderate insulin injection complications. There was statistical significant difference between patients' total systematic insulin injection complications in relation to their personal characteristics including age, residency, and level of education, and onset of insulin injection treatment $(\mathrm{P}<0.05)$.

\section{Recommendations:}

According to results of the current study, the following suggestions are recommended:

(1) Periodic health teaching programs for diabetic patients and family including diabetes self management, education of correct insulin injection technique and insulin injection complications and its preventive and curative management, and clinical management to improve their management of the disease.

(2) Prospective follow up studies are needed to develop and refine intervention to improve compliance of diabetic patients and prevention of short and long term complications.

(3) Emphasizing the importance of more prospective studies to shed light on the factors that hinder the glycemic control of diabetic patients and their adherence with insulin therapy and how to overcome them to ensure their compliance.

(4) Further studies on insulin injection complications to evaluate the important of including the suggested nursing management guidelines on the patient's care including complications.

\section{References}

Abd El-Aziz, M.A., (2007): Quality of life for adolescents with type 1 diabetes mellitus, unpublished 
Rasha Attia Hafez Al shabrawy et. al.

master thesis, faculty of nursing, Ain Shams University, pp.72-90.

Abd El-Ghafar, A., (2003): Factors Affecting Self Care Practices of Diabetic School Students in Alexandria, Master Thesis, Faculty of Nursing, Alexandria University,pp.67-120.

Abd El-Mohmen, H., (2012): Home care for adolescent wiyh type 1 diabetes in rural areas at Kolyobiagovernerate, master thesis, faculty of nursing, faculty of nursing, Benha university, pp.67-70.

Abdel Hamid, S.H., (2005): Self Care Practice Among Home Based Diabetic Elderly in Dakahlia Governorate, Master Thesis, Faculty of Nursing, Alexandria University.

Abu-Samra, O.M.,(2005):Factors affecting diabetes control in children with type 1 diabetes, Master thesis, Faculty of nursing, Ain Shams university, pp. 26-48.

American Association of Clinical Endocrinologists (AACE), (2013): Comprehensive Diabetes Management Algorithm, Endocrine Practice, v19 (2), p.336.

\section{American Association of Diabetes Educators(AADE), (2011): Strategies for Insulin Injection Therapy in Diabetes Self- Management,Available at:http://www.diabeteseducator.or g/DiabetesEducation/position/, accessed on: 7/1/2015.}

American Diabetes Association (ADA), (2014): Standards of Medical Care in Diabetes, Position statement, Diabetes Care, diabetesjournals.org V37 (1), pp. 14-75.

Amiel, S., Beveridge,S., Bradley,C., Gianfrancesco,C., Heller,S., James,PMcKeown, N., Newton,O., Newton, L., Oliver,L .,Reid,H.,Roberts,S., Robson, S.,Rollingson,J .,Scott, V., $\quad$ Speight,J., Taylor,C.,Thompson,G., Turner,E., andWright,F., (2002):Training in flexible, intensive insulin management to enable dietary freedom in people with type 1 diabetes: dose adjustment for normal eating (DAFNE) randomized controlled trial, DAFNE Study Group BMJ., v 325, PP.1-6.

Antinori-Lent, K., (2013): Improving insulin adherence in diabetes care, American Nurse Today, v8 (9),PP.13-15, availableat: http://www.AmericanNurseToda y.com.

Atkinson, M., (2012): The pathogenesis and natural history of type 1 diabetes, Cold Spring Harbor Perspectives in Medicine, v 2(11),pp.1-16, Retrieved March 30,2013 , from perspectives in medicine, available at:http://www.ncbi.nlm.nih.gov/p mc/articles/PMC3543105.

Attia, W., (2012): Assess knowledge and practice of caregivers for school age children with type 1 diabetes mellitus, unpublished 
master thesis, faculty of nursing, Benha University, pp.113-122.

Bajwa, S., Kalra, S., Baruah, M., and Bajwa, K., (2013):An acute need for awareness of insulin injection guidelines in operative and intensive care units, Anesthesia: Essays and Researches, v7(1), P.1.

Blanco, M., Hernández, M.T., Strauss, K.W., and Amaya, M., (2013): Prevalence and risk factors of lipohypertrophy in insulin-injecting patients,39(5), pp.445-453.

Butalia, S., Johnson, J., Ghali, A. W., and Rabi1, D. M., (2013): Complications Clinical and sociodemographic factors associated with diabetic ketoacidosis hospitalization in adults with Type 1diabetes, Diabetic Medicine, v30, pp.567-573.

Cho, Y.M., Kim, M., and Park, K.S. (2003): "S20G Mutation of the Amylin Gene is Associated with A lower Body Mass Index in Korean Type 2 Diabetic Patients", Diabetes Res.,ClinPract., v60 (2), p.p.12529.

Chowdhury, T., Escudier, V., (2003): Poor glycaemic control caused by insulin induced lipohypertrophy, BMJ., v327, pp.383-384.

Clark, LF.,Bilbie, JC., and Abraham. P., (2011): What do patients prefer: insulin pumps or multiple daily injections and structured education?PractDiab Int., v28 (2), pp.73-75.
Conrad .M., and Ferry .R., (2014):Insulin Resistance, available at: http://www.medicinenet.com/insu lin_resistance/article.htm, accessed on: 21/10/2014.

Cunningham, MT., and McKenna, MJ., (2013): Lipohypertrophy in insulin-treated diabetes: Prevalence and associated risk factors, Journal of Diabetes Nursing, v17, pp.340-343

David, G.,(2011): Dolores Greenspan's basic \& clinical endocrinology, New York:McGraw-Hill Medical, $9^{\text {th }}$ Ed, Chapter 17.

Diabetes Control and Complications Trial / Epidemiology of Diabetes,(2009): Interventions and Complications and Pittsburgh Epidemiology of Diabetes Complications experience, DCCT / EDIC Research Group, Modernday clinical course of type1 diabetes mellitus after 30 years' duration, Arch Intern Med. , v169, pp.1307-1316.

Donna, D., Linda, M.,(2013):care of patients with diabetes, patient centered collaborative care, ,medical surgical nursing text book, $7^{\text {th }}$ ed, John Wiley and sons, Inc, chapter 67, pp.1413-1463.

Dunning, T., Rosen, S., and Alford, F., (1998): Insulin allergy: a rare diagnostic and management dilemma, Journal of Diabetes Nursing, v2 (6),pp. 188-190. 
Galal, B., (2009): Factors Affecting Compliance of Diabetic Patients toward Therapeutic Management, unpublished master thesis, faculty of nursing, Zazig University, pp.78-87.

Galal, B., (2012): Effect of educational program on self efficacy for patient with type2 diabetes mellitus, Doctorate thesis, faculty of nursing, Benha University, pp.119-129.

Hamed, M., (2001)The effect of self care program on self care cognition and quality of life among outpatient diabetics at Benha university hospital, Doctorate thesis, faculty of nursing, Benha university, pp.8192

Hansen, B., Kirketerp, G., Ehlers, G., Nordentoft, E., and Hansen, G., (2007): Evidence-based clinical guidelines for injection of insulin for adults with diabetes mellitus, $2^{\text {nd }}$ ed, Dansk Sygeplejerad (Danish Nurses Organization), Kopenhagen, available

at:http://www.dsr.dk/artikler/docu ments/english/evidencebased clin ical_, accessed on 12/1/2014.

Hirsch, IB., Bode, BW., and Childs, BP., et al., (2008): Selfmonitoring of blood glucose (SMBG) in insulin- and noninsulin-using adults with diabetes: consensus recommendations for improving SMBG accuracy, utilizationand research, Diabetes TechnolTher., v 10, pp.419-39.
Hirsch, L., Gibney, M., Berube, J., Manocchio, J., (2012): Impact of a Modified Needle Tip Geometry on Penetration Force as well as Acceptability, Preference, and Perceived Pain in Subjects with Diabetes, Journal of Diabetes Science and Technology, v 6(2), PP.328-335.

Ismail, N., Kasem, O., and Abou-ElAsrar, M.,(2008): Epidemiology and Management of Type 1 Diabetes Mellitus at the Ain Shams University Pediatric Hospital, J Egypt Public Health Assoc., v 83 (1 \& 2), P 108.

Jones, S., and Smithys, L., (2005): The changing proportions of the growing body, Recognizable patterns of human malformation, $6^{\text {th }}$ ed Philadelphia: Saunders, SD., pp.234-235.

Kamel, R., (2012): Assessment of patients complications under anesthesia and general surgery, unpuplisded master thesis, faculty of nursing, Benha university.pp.46-49.

Khardori, R., and Griffing, G., (2013): Type 1 Diabetes Mellitus Treatment \& Management,Medscape Medical News, Availableat:http:// www. emedicine. medscape.com/ article/117739treatment, accessed on: $13 / 1 / 2014$

King, H., Aubert, R.E., and Herman, W.H., (1998): Global burden of diabetes, 1995-2025: prevalence, numerical estimates 
and projections, Diabetes Care, v21 (1), pp. 1414-1431.

Kitabchi, A.E., Umpierrez, G.E., Fisher, J.N., Murphy, M.B., and Stentz, F.B., (2008): Thirty years of personal experience in hyperglycemic crises: diabetic ketoacidosis and hyperglycemic hyperosmolar state, Journal of clinical Endocrinology and metabolism, v93 (5), pp.15411552.

Knip, M., (2011): Pathogenesis of type 1 diabetes: implications for incidence trends, Hormone Research in Pediatrics, v76 (1), PP.57-64.

Kohlaway, E., (2008): New Alamance Confronts, The high Costs ofChronic Disease Electronic Publication Retrieved June 25, 2010, Available at: Url:www.fightchronicdiseases.or $\mathrm{g} /$ resources.

Mccane,K.L.,Huether.,S.E.,Brasher s,V.,andRote,N.,(2010):pathophy siol-ogy, the biological basis for disease in adults $\&$ children, $6^{\text {th }}$ ed, Missouri: Mosby Elsevier, chapter2.

McGibbon, A., Richardson, C., Hernandez, C., and Dornan, J., (2013): Pharmacotherapy in Type 1 Diabetes, Canadian Diabetes Association Clinical Practice Guidelines Expert Committee, Can J Diabetes, v37 (1) S.556.

Mohammed, H.S., (2003): The effect of health education program on psychological and adjustment of children with insulin dependent diabetes mellitus, unpublished Doctorate thesis, faculty of nursing, Assiut University, pp.8896.

Mohammed, W.A., (2008): A study on the pattern of growth of diabetic preschool and school children, unpublished master thesis, faculty of nursing, Assuit University, pp.86-95.

Moustafa, S., (2011): Effect of educational program on improving quality of life of diabetic children and adolescents, Doctorate thesis, faculty of nursing, Benha University, pp.133-146.

Munib, A., (2009): Cutaneous complications of insulin therapy in patients with type 1 diabetes mellitus, J Fac Med Baghdad, v 51(4), PP 353-356.

Nafee, H.M., and Awad, L., (2008): Knowledge of parents, teacher, and school nurse about insulin dependant diabetes mellitus, Alexandria scientific Nursing Journal, v7 (2), pp.147-167.

Oski, F., De Angelis, C., Fegigin, R., and Mashow, J., (2005): Principles and practices of pediatrics, Lippincolt company, London, pp.1811-1815.

Pledger, J, Hicks, D, Kirkland, F, and Down, S., (2012): Importance ofinjection technique in diabetes Journal of Diabetes Nursing, v16 (4) PP.162-163.

Ratzan, D.G., (2000): Immunological characterization and therapeutic 
Rasha Attia Hafez Al shabrawy et. al.

activity of altered peptide, Diabetes care, v51, pp.21262134.

Redondo, MJ., Jeffrey, J., Fain, PR., Eisenbarth, GS., and Orban, T., (2008): Concordance for islet autoimmunity among monozygotic twins, N Engl J Med., v 359(26), pp.2849-50.

Rewers, A., Chase, P., Mackenzie, T., Walravens, P., and Roback, M., (2010): Predictors of acute complications in children with type 1 diabetes, v1 (12), pp.358366.

Riaz, M, Basit, A., and Ali Rizvi, z., (2014): Factors associated with non- adherence in patients with type 1 diabetes, Pakistan Journal of Medical Sciences Pak JMed Sci., v30(2), pp. 233-239.

Richardson, T., and Kerr, D., (2003): Skinrelated complications of insulin therapy: Epidemiology and emerging management strategies, Am J ClinDermatol., v4 (10), p.p.661-667.

Salem, M., El-Samahy, M., and Sohi, A., (1991): Evolution of nutritional status and dietary pattern in Egyptian diabetec children, Journal of pediatric, v8 (1\&2), pp.59-65.

Selim, M., (2000): Adherence to Treatment Regimen among Selected Sample of Egyptian Insulin Dependent Diabetic Patients, The New Egyptian Journal of Medicine, v1 (3): 12835.
Shaw, JE.,Sicree, RA., and Zimmet, PZ., (2010): Global estimates of the prevalence of diabetes for 2010 and 2030, Diabetes Res.Clin. Pract., v87(1), p.p.4-14.

Shobana, R., Begum, R., Snehalatha, C., Vijay, V., and Ramchandran, A., (1999): Patients' Adherence to Diabetes Treatment, J Assoc Physicians India., v47, pp.1173-1175.

Smith, N., and Cockrell, L.M., (2013): Diabetes mellitus, type1, available at:http://www. nursingceu. com/ courses/ 423/ index nceu.html, accessed on: 6/1/2015.

Torrance,T.,(2008): Effect of insulin needle reuse, size and site of injection on the risk of bending and breaking, Journal of Diabetes Nursing, v12 (1), p.30.

Vardar, B., and Kizilci, S., (2007): Incidence of lipohypertrophy in diabetic patients and a study of influencing factors, Diabetes Res ClinPract., v77 (2), pp.231-236.

Villiers, F.,( 2006):Lipohypertrophy a complication of insulin injections JEMDSA, Department of Pediatrics and Child Health, Medunsa Campus, University of Limpopo, PO Box 221, Medunsa, 0204, V 11(2).

Wilkin, TJ., (2009): The accelerator hypothesis: a review of the evidence for insulin resistance as the basis for type 1 as well as type II diabetes, Int J Obes., v33, pp.716-72 